\title{
Effect of acupuncture TENS versus conventional TENS on post cesarean section incision pain
}

\author{
Priti A. Mehendale ${ }^{1 *}$, Mayur T. Revadkar ${ }^{2}$
}

\begin{abstract}
${ }^{1}$ Department of Musculoskeletal Physiotherapy, ${ }^{2}$ Department of Community Physiotherapy, K. J. Somaiya College of Physiotherapy, Mumbai, Maharashtra, India
\end{abstract}

Received: 05 July 2018

Revised: 08 August 2018

Accepted: 10 August 2018

*Correspondence:

Dr. Priti A. Mehendale,

E-mail: priti.a.mehendale@gmail.com

Copyright: ( ) the author(s), publisher and licensee Medip Academy. This is an open-access article distributed under the terms of the Creative Commons Attribution Non-Commercial License, which permits unrestricted non-commercial use, distribution, and reproduction in any medium, provided the original work is properly cited.

\begin{abstract}
Background: There is evidence regarding beneficial use of Transcutaneous Electrical Nerve Stimulation (TENS) on post Lower Segment Caesarean Section (LSCS) incision pain. However, efficacy of different types of TENS following $\mathrm{C}$ section pain has not yet been explored adequately.

Methods: 96 women who had recently undergone LSCS were included for the study. The subjects were in the age group of 20 to 40 years $(25.84 \pm 3.96)$; having pain intensity 4 or more on Numerical Pain Rating Scale (NPRS). They were divided into three groups by random allocation method; namely Group A: Acupuncture (Low/Motor) TENS, Group B: Conventional (High/Sensory) TENS and Group C: Control group. Group A and B received specific type of TENS twice a day for 15 minutes. Control group $\mathrm{C}$ did not receive any TENS intervention. All subjects received standard post-operative medications and physiotherapy. Pain intensity was recorded on NPRS pre and post intervention.

Results: Both Acupuncture TENS and Conventional TENS significantly decreased post-operative pain intensity as compared to control group ( $\mathrm{p}$ value $<0.0001$ ).

Conclusions: Both, acupuncture and conventional TENS are equally effective in reducing post LSCS incision pain at a strong and non-painful intensity.
\end{abstract}

Keywords: Acupuncture TENS, Conventional TENS, LSCS, Pain

\section{INTRODUCTION}

Caesarean sections are effective in saving maternal and infant lives when medically indicated. The caesarean section rate as per WHO statistics which is supposed to be at an optimal $10 \%$ has increased in last two decades. WHO statistics show that in India caesarean section birth accounts for about $17.2 \%$ of all the births. ${ }^{1}$

Caesarean section is commonly done by Pfannenstiel (bikini line) incision. ${ }^{2,3}$ As with other abdominal surgeries, many women experience significant suture site pain following LSCS. This continuous incision site pain is a result of the subsequent inflammatory reactions involved in the operative process.

It has a negative influence on puerperal women, since it makes recovery more difficult, delays early mobility and contributes to delay in bonding of mother with the newborn. Besides, it impacts the breastfeeding process as, due to pain it becomes more difficult to find a comfortable body position to breastfeed. ${ }^{4}$ 
Transcutaneous electric nerve stimulation (TENS) is a physiotherapeutic resource commonly used for symptomatic management of acute and chronic pain. It acts by relieving pain, replacing or complementing analgesics. Pain relief brought by TENS is based partly on the pain gate theory, proposed by Melzack and Wall in 1965 and partly on the descending pain pathway modulation. According to pain gate theory, painful perception modulation by TENS is attributed to the recruitment of afferent $A \beta$ fibres in spinal cord dorsal horn, which would prevent or make difficult the activation of fibres which conduct pain. Pain modulation by TENS via the descending pain pathway is through release of endorphins, serotonin, and enkephalin. ${ }^{5,6}$

There are many different types of TENS, such as conventional, acupuncture, modulated, burst, and brief intense TENS, which vary according to intensity, frequency and pulse characteristics. Commonly used TENS are Conventional, Acupuncture and Brief intense TENS. ${ }^{7,8}$

TENS units are typically of two types: electrically operated and battery operated (portable). TENS is delivered by silicon impregnated carbon rubber electrodes. They are secured to the site by straps and/or adhesive tape. Sterile electrode gel is the commonly used conducting medium. This helps transmit the TENS impulses through the skin; hence the term 'transcutaneous'.

There is evidence regarding effective use of TENS post abdominal surgeries including caesarean section for incisional pain. Although it is an effective adjunctive therapy for postoperative pain, the effects of different frequencies and intensities of stimulation have not yet been systematically investigated. ${ }^{9}$ Recent evidence regarding use of Acupuncture TENS in post $\mathrm{C}$-section is limited. Hence the study was undertaken to determine the efficacy of Acupuncture TENS in post C-section incision pain.

\section{METHODS}

Table 1: Numerical pain rating scale.

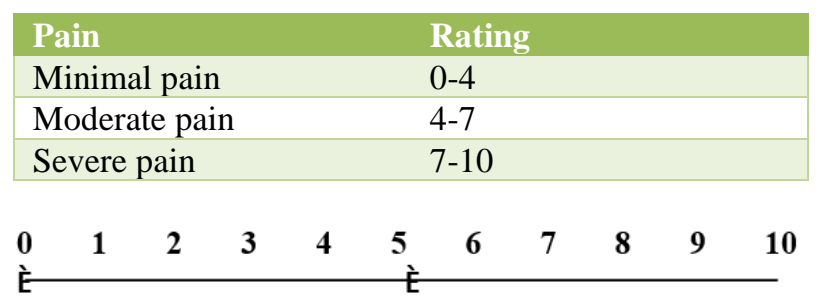

Sample size was calculated using openepi software and as per previous studies. After obtaining institutional ethical committee approval, 96 subjects in the age group of 20 to 40 years $(25.84 \pm 3.96)$; who had recently undergone either elective or emergency LSCS in a tertiary care centre, having moderate pain (intensity 4 or more on numerical Pain Rating Scale (NPRS) (Table 1) and willing to participate were included in the study. ${ }^{10}$ Women with any post-partum complications such as post-partum haemorrhage and/or any condition that contraindicated application of TENS were excluded from the study.

Table 2: Demographic details.

\begin{tabular}{|llll|}
\hline Variable & Group A & Group B & Group C \\
\hline Age (years) & Acupuncture $(\mathbf{n = 3 2})$ & Conventional $(\mathbf{n = 3 2})$ & Control $(\mathbf{n = 3 2})$ \\
\hline Primi-parous & $26.12 \pm 3.57$ & $25.62 \pm 3.73$ & $25.78 \pm 4.44$ \\
\hline Multi-parous & $\mathrm{n}=16$ & $\mathrm{n}=14$ & $\mathrm{n}=15$ \\
\hline Elective LSCS & $\mathrm{n}=16$ & $\mathrm{n}=18$ & $\mathrm{n}=17$ \\
\hline Emergency LSCS & $\mathrm{n}=20$ & $\mathrm{n}=21$ & $\mathrm{n}=20$ \\
\hline
\end{tabular}

After obtaining informed written consent from the subjects, they were divided into three groups by random allocation method; namely Group A: Acupuncture TENS, Group B: Conventional TENS and Group C: Control group. All subjects received standard post-operative medications as prescribed by the obstetrician. Study procedure was explained in detail to all subjects in the language best understood by them and general information was documented after taking informed written consent (Table 2). TENS was administered to subjects, minimum of 12 hours post LSCS; to prevent acute interferences in post anaesthetic recovery. Group A received Acupuncture TENS (Frequency $2 \mathrm{~Hz}$ ) and Group B received conventional TENS (frequency 120 $\mathrm{Hz}$ ) for 15 minutes twice a day at a maximum intensity comfortably tolerated. ${ }^{11}$

Transcutaneous Electrical Nerve stimulation unit was used with 4 rubber electrodes. Treatment was given in a crook lying position. Electrodes were placed in a crossed pattern with close proximity to suture site over the incision, two being above and two below the incision. Conductive hypoallergenic gel and micro pore tape was used to fix the electrode for good skin adherence. ${ }^{5,12}$ 
Table 3: Standard post-natal physiotherapy regimen after caesarean section.

\begin{tabular}{|c|c|}
\hline $\begin{array}{l}\text { Breathing } \\
\text { exercises }\end{array}$ & $\begin{array}{l}\text { Deep breathing exercises. Inspiration } \\
\text { with pursed lip expiration followed } \\
\text { by huffing/ coughing. }\end{array}$ \\
\hline $\begin{array}{l}\text { Core } \\
\text { activation }\end{array}$ & $\begin{array}{l}\text { Gentle in drawing of the lower } \\
\text { abdomen, held for } 5-10 \text { seconds. No } \\
\text { holding of breath. Crook lying position. } \\
\text { Static abdominal contraction held for } \\
5-10 \text { seconds. Supine/crook lying } \\
\text { position. }\end{array}$ \\
\hline $\begin{array}{l}\text { Pelvic floor } \\
\text { exercises }\end{array}$ & $\begin{array}{l}\text { Slow, controlled contractions of the } \\
\text { pelvic floor followed by fast short } \\
\text { contractions of the pelvic floor muscles } \\
\text { performed in crook lying position. 5-10 } \\
\text { repetitions of each. Repeated every } \\
\text { couple of hours. Isometric gluteal } \\
\text { contractions (each held for 5-10 } \\
\text { seconds), repeated every couple of } \\
\text { hours. Crook lying/supine position. } \\
\text { Pelvic tilt in the crook lying position. }\end{array}$ \\
\hline Ergonomics & $\begin{array}{l}\text { Support sutures while coughing. } \\
\text { Adequate low back support during } \\
\text { sitting and breast feeding. }\end{array}$ \\
\hline
\end{tabular}

Group C did not receive any TENS intervention. Subjects in all three groups received standard postnatal physiotherapy i.e. breathing exercises, bed mobility exercises, core exercises, ergonomic advice and postural care regarding breastfeeding positions (Table 3). Pain intensity was assessed using NPRS, pre and post intervention. Data thus collected was further subjected to statistical analysis. ${ }^{2,13}$

\section{RESULTS}

Table 4: Comparative results of pain assessment on numerical rating scale.

\begin{tabular}{|llllllll|} 
& \multicolumn{2}{c}{ Group A } & \multicolumn{2}{c}{ Group B } & \multicolumn{2}{c|}{ Group C } \\
& Pre & Post & Pre & Post & Pre & Post \\
\hline Mean & 7 & 4.62 & 6.62 & 4.40 & 6.62 & 5.87 \\
\hline SD & 1.73 & 1.76 & 1.59 & 1.57 & 1.63 & 1.61 \\
\hline Max & 10 & 9 & 10 & 7 & 10 & 9 \\
\hline Min & 5 & 0 & 4 & 1 & 4 & 3 \\
\hline
\end{tabular}

Statistical analysis was done using graph pad instant software. Table 4 shows the mean difference in pain reduction as measured on NPRS.

Table 5: Comparison of NPRS scores between the groups prior to intervention.

\begin{tabular}{|lllll|}
\hline & Group A & Group B & Group C & p-value \\
Mean & 7 & 6.62 & 6.62 & 0.6770 \\
\hline SD & 1.73 & 1.59 & 1.63 & Not \\
Max & 10 & 10 & 10 & significant \\
\hline Min & 5 & 4 & 4 & \\
\hline
\end{tabular}

Comparison of the Pre NPRS-score (prior to intervention) in between the three groups using Kruskal-Wallis test, $(\mathrm{P}=0.6770)$ indicated that all three groups were comparable (Table 5).

Table 6: Comparison of NPRS scores between the groups post intervention.

\begin{tabular}{|lllll|}
\hline & Group A & Group B & Group C & p-value \\
\hline Mean & 4.62 & 4.40 & 5.87 & \\
\cline { 1 - 2 } & 1.76 & 1.57 & 1.61 & 0.0047 \\
Max & 9 & 7 & 9 & Very \\
Min & 0 & 1 & 3 & significant \\
\hline
\end{tabular}

Comparison of the Post NPRS-score (Post intervention) in between the three groups using Kruskal-Wallis test showed $\mathrm{P}$ value as 0.0047 ; i.e. very significant. indicating that there was statistically significant effect post intervention (Table 6).

Table 7: Dunn's multiple comparison test.

\begin{tabular}{|lll|}
\hline $\begin{array}{l}\text { Group A (acupuncture } \\
\text { TENS) versus Group B } \\
\text { (conventional TENS) }\end{array}$ & $>0.05$ & Not significant \\
\hline $\begin{array}{l}\text { Group A (acupuncture } \\
\text { TENS) versus Group C } \\
\text { (Control) }\end{array}$ & $<0.05$ & Significant \\
$\begin{array}{l}\text { Group B (conventional } \\
\text { TENS) versus Group C } \\
\text { (Control) }\end{array}$ & $<0.05$ & Significant \\
\hline
\end{tabular}

Further, Dunn's Multiple Comparison test was performed to analyse which group showed most effective difference post intervention (Table 7). It reveals that any type of TENS was effective as compared to control group (P value $<0.05)$.

Table 8: Comparison of difference of pre-post NPRS scores in between the interventional Group A and B.

\begin{tabular}{|llll} 
& Group A & Group B & p-value \\
$\begin{array}{l}\text { Difference of } \\
\text { mean (pre-post) }\end{array}$ & 2.38 & 2.22 & 0.6609 \\
& & & Not significant \\
\hline
\end{tabular}

Applying Mann-Whitney test (Table 8), compared the efficacy of acupuncture TENS (Group A) versus conventional TENS (Group B). It revealed that acupuncture TENS was as effective as conventional TENS in reducing post LSCS suture pain.

Thus, both the interventional groups (A and B) were effective in reducing post LSCS incision pain, as compared to control group (C). Amongst the interventional groups, acupuncture TENS was found to be equally effective as conventional TENS in reducing post LSCS incision pain. 
Parity wise, amongst multiparous and primiparous women it was found that, pain relief by acupuncture and conventional TENS was extremely significant as compared to no intervention. Wilcoxon's pair matched test and Paired T test were used to statistically analyse the data for the effect of different types of TENS on primiparous and multiparous women. (Table 9 to 12).

Table 9: Parity wise effect of different type of TENS on pain as measured on NPRS (multiparous women).

\begin{tabular}{|lllllll|} 
& Group A & (Acupuncture TENS) & \multicolumn{2}{c|}{ Group B (Conventional TENS) } & \multicolumn{3}{c|}{ Group C (Control Group) } \\
\hline & Pre & Post & Pre & Post & Pre & Post \\
\hline Mean & 6.31 & 4 & 6.75 & 5.06 & 6.56 & 6.06 \\
\hline SD & 1.44 & 1.31 & 1.43 & 1.34 & 1.5 & 1.8 \\
\hline
\end{tabular}

Table 10: Statistical analysis- parity wise effect of different type of TENS on pain as measured on NPRS (multiparous women).

\begin{tabular}{|c|c|c|c|c|c|c|c|c|}
\hline \multicolumn{3}{|c|}{ Group A (Acupuncture TENS) } & \multicolumn{3}{|c|}{ Group B (Conventional TENS) } & \multicolumn{3}{|c|}{ Group C (Control Group) } \\
\hline Test & p-value & Interpretation & Test & p-value & Interpretation & Test & p-value & Interpretation \\
\hline $\begin{array}{l}\text { Wilcoxon } \\
\text { matched } \\
\text { pair test }\end{array}$ & $<0.0001$ & $\begin{array}{l}\text { Extremely } \\
\text { significant }\end{array}$ & $\begin{array}{l}\text { Wilcoxon } \\
\text { matched } \\
\text { pair test }\end{array}$ & $<0.0001$ & $\begin{array}{l}\text { Extremely } \\
\text { significant }\end{array}$ & $\begin{array}{l}\text { Wilcoxon } \\
\text { matched } \\
\text { pair test }\end{array}$ & & \\
\hline
\end{tabular}

Table 11: Parity wise effect of different type of TENS on pain as measured on NPRS (primiparous women).

\begin{tabular}{|llllllll|}
\hline & Group A & (Acupuncture TENS) & Group B (Conventional TENS) & \multicolumn{2}{c}{ Group C (Control Group) } \\
\hline & Pre & Post & Pre & Post & Pre & Post \\
\hline Mean & 7.68 & 5.25 & 6.28 & 3.64 & 6.96 & 5.8 \\
\hline SD & 1.81 & 2.01 & 1.81 & 1.59 & 1.68 & 1.47 \\
\hline
\end{tabular}

Table 12: Statistical analysis- parity wise effect of different type of TENS on pain as measured on NPRS (primiparous women).

\begin{tabular}{|lllllllll}
\hline Group A & (Acupuncture TENS) & \multicolumn{2}{c}{ Group B (Conventional TENS) } & \multicolumn{3}{c}{ Group C (Control Group) } \\
\hline Test & p-value & Interpretation & Test & p-value & Interpretation & Test & p-value & Interpretation \\
$\begin{array}{l}\text { Paired T } \\
\text { test }\end{array}$ & $<0.0001$ & $\begin{array}{l}\text { Extremely } \\
\text { significant }\end{array}$ & $\begin{array}{l}\text { Wilcoxon } \\
\text { matched } \\
\text { pair test }\end{array}$ & 0.0002 & $\begin{array}{l}\text { Extremely } \\
\text { significant }\end{array}$ & $\begin{array}{l}\text { Wilcoxon } \\
\text { matched } \\
\text { pair test }\end{array}$ & $0.0156 \quad$ Significant \\
\hline
\end{tabular}

\section{DISCUSSION}

The present study aimed at finding out the comparative effectiveness between conventional TENS and acupuncture TENS in post LSCS incision pain. The study revealed that interventional groups had significant pain relief as compared to control group. Among the interventional groups, it showed conventional as well as acupuncture TENS were equally effective in bringing about pain relief.

Pain is defined as an unpleasant sensory and emotional experience associated with actual or potential tissue damage as put forward by International Association for the Study of Pain. Pain after surgery is a very specific entity, being the result of an inflammatory process and injury to nerves. Although inflammation and neural tissue damage occur, the pathophysiology of postoperative pain is unique, and the consequences are specific. ${ }^{14}$ Pain sensation is transmitted by the $\mathrm{A} \delta$ and $\mathrm{C}$ nerve fibres. The A $\delta$ receptors respond to strong mechanical stimulation and to damaging heat above $45^{\circ} \mathrm{C}$. When these fibres are stimulated, they cause prickling or stinging sensation known as first or fast pain. A $\delta$ receptors are present mainly in the skin and to some extent in the joints and muscles. Impulses travel at a speed of $15 \mathrm{~m} / \mathrm{s}$ along myelinated nerve fibres. ${ }^{7,15}$

C fibre receptors respond to mechanical, chemical and heat stimuli. They are sensitive to chemicals released from tissue damaged by any stimulus. This include inflammatory changes leading to release of hydrogen ions, histamine, serotonin, prostaglandins $\mathrm{E}$ and $\mathrm{F}$ as well as ATP, ADP and Lactic acid. Their stimulation gives rise to dull aching or slow pain. The $\mathrm{C}$ fibre receptors (free nerve endings) are found all over the body. Impulses travel at a speed of $1 \mathrm{~m} / \mathrm{s}$ along unmyelinated nerve fibres. ${ }^{7,16}$ The cell bodies of $\mathrm{A} \delta$ and $\mathrm{C}$ fibres are found in the dorsal root ganglion and their central connections 
enter the spinal cord via the dorsal root. Here they synapse with central nociceptive transmission cells. From here information is transmitted via the spinothalamic tract or via the spinoreticular tract to the thalamus. From the thalamus information is transmitted to the somatosensory cerebral cortex and other regions of the brain. The substance $\mathrm{P}$ is the main neurotransmitter of this nociceptive system. ${ }^{7,17}$

Any surgical procedure causes tissue damage and sets in an inflammatory process; the symptoms being pain and loss of function. Thus, if effectively managed will go a long way in providing early return to activity and bonding with the baby post LSCS. Post LSCS pain management includes non-steroidal anti-inflammatory drugs and TENS. TENS has added advantage of being non-invasive and having no side effects. ${ }^{18,19}$

TENS is a widely used modality for pain relief in physiotherapy and there are variations in its parameters having various effects. It activates complex neuronal network to reduce pain by activating descending inhibitory systems in the central nervous systems to reduce hyperalgesia. Both conventional and acupuncture TENS are known to provide analgesia, specifically when applied at a strong, non-painful intensity, at frequencies and intensities used clinically. Although, both types of TENS provide pain relief, they do so by different mechanisms. ${ }^{20}$

Conventional TENS uses high frequency, low intensity pulses. (12-30 mA, 100-150 Hz) It is perceived as strong comfortable electrical aesthesia with no muscle activity. It has been associated with moderate pain relief lasting up to 2-3 hours post application. These impulses stimulate large diameter $A \beta$ fibers. These fibers give off collaterals, which impinge on nociceptor cells of $\mathrm{A} \delta$ and $\mathrm{C}$ pain fibers in laminae of the posterior horn of spinal cord. It is believed that the input of these mechanoreceptors effectively reduces the excitability of the nociceptor cells to pain generating stimuli; referred to as presynaptic inhibition. This is what is popularly known as gate control theory of pain, suggested by Melzack and Wall in 1965. It also puts forth that pain perception is regulated by 'gate' which may be opened or closed by means of other inputs from peripheral nerves or from central nervous system, thus increasing or decreasing the pain perceived. This type of pain relief is brought about by the high frequency, low intensity conventional type of TENS. ${ }^{21,22}$

Patients experience acupuncture TENS as a strong comfortable electrical paresthesia with an occasional muscle twitch. It provides pain relief typically lasting 6-7 hours post application. ${ }^{14}$ Morphine acts on the $\mathrm{C}$ fibers system and hence controls tissue damage pain. It imitates naturally occurring group of neurotransmitters, encephalin, endorphin and dynorphin. In the substantia gelatinosa there are interneurons which can produce encephanlin to inhibit the $\mathrm{C}$ system cells in this region.
Collateral branches of A $\delta$ fibers in the posterior horn connect with these interneurons and stimulate them. Thus, stimulation of the A $\delta$ fibers by electrical impulses will damp down $\mathrm{C}$ fibers system type pain. This is the postulated mechanism of pain relief by acupuncture TENS (1-5 Hz and above 30 milli-amperes). ${ }^{7,21}$

Morphine type of effect on $\mathrm{C}$ fiber system by conventional TENS but involving the centers in midbrain and serotonin as neurotransmitter, has been postulated. Activation of $A \delta$ pain fibers provokes impulses in midbrain that travel back down in the spinal cord to inhibit nociceptive neuron at the original level. A $\delta$ nociceptors in the spinothalamic tract give off collaterals branches to periaqueductal grey matter (PAG) in the midbrain. Descending neurons from this region pass to various subregions of the rostral ventral medulla and then to the spinal dorsal horn generating serotonin and noradrenaline in the substantia gelatinosa. This is commonly known as descending pain suppression pathway. $7,16,17$

\section{CONCLUSION}

The study explored the alternative use of acupuncture TENS with a view of providing longer lasting analgesia as opposed to conventional TENS. While proving that any type of TENS (conventional/acupuncture) is better than no TENS at all; also showed that acupuncture TENS is as effective as conventional TENS in management of post LSCS incision pain.

\section{ACKNOWLEDGMENTS}

Authors would like to thank Dr. Kamlesh Chaudhari, Head of the Department of Gynaecology and Obstetrics, K. J. Somaiya Medical College and Hospital for the help and cooperation. Also, authors would like to extend their gratitude to Dr. Dipak Patil, Assistant Professor, Department of Community Medicine, K. J. Somaiya Medical College for his guidance for the statistics.

Funding: No funding sources Conflict of interest: None declared

Ethical approval: The study was approved by the Institutional Ethics Committee

\section{REFERENCES}

1. WHO statements of caesarean section rates. April 2015. WHO reference No. WHO/RHR/15.02. Available at: http://www.who.int/reproductivehealth/publications/ maternal_perinatal_health/cs-statement/en/

2. Barton S. The Postnatal Period. In: Mantle J, Haslam J, Barton S, editors. Physiotherapy in Obstetrics and Gynecology. $2^{\text {nd }}$ edition. Edinburgh: Elsevier; 2004. 237-240..

3. Dutta DC. Textbook of Obstetrics including perinatology and Contraception. 7th Edition. 
Kolkata: New Central Book agency Pvt Ltd;2011. Chapter 26, Operative Obstetrics;588-591.

4. Lima LE, Lima AS, Rocha CM, Santos GF, Bezerra AJ, Hazime FA, et al. High and low frequency transcutaneous electrical nerve stimulation in postcaesarean pain intensity. Fisioter Pesq. 2014;21(3):243-8.

5. Johnson M. Transcutaneous electrical nerve stimulation (TENS). In: Kitchen S, editor. Electrotherapy Evidence Based Practice. $11^{\text {th }}$ ed. New Delhi: Elsevier; 2006. 259-275.

6. Alves E, Nazario R, Ries S, Guimaraes S, Leite L, Santos S. Transcutaneous electric nerve stimulation for post-Caesarean section analgesia. Rev Dor. 2015;16(4):263-6.

7. Low J, Reed A. Electrotherapy Explained Principles and Practice. $3^{\text {rd }}$ Edition. Oxford: ButterworthHeinemann; 2000. Chapter 3, Electrical Stimulation of Nerve and Muscle;113-118.

8. Robertson V, Ward A, Low J, Reed A. Electrotherapy Explained Principles and Practice. 4th Edition. New Delhi: Elsevier; 2006. Chapter 6, Sensory Stimulation and other uses; p. 171-183.

9. Josimari M, Kathleen A, Gabriela R. High and low frequency TENS reduce postoperative pain intensity after laparoscopic tubal ligation: a randomized controlled trial. Clinic J Pain. 2009;25(1):12-9.

10. White DJ. Musculoskeletal Examination. In: O'Sullivan S, Schmitz T, editors. Physical Rehabilitation. 5th Edition. Philadelphia. F. A. Davis Company. 2007. 163-164.

11. Moran F, Leonard T, Hawthorne S, Hughes CM, McCrum-Gardner E, Johnson MI, et al. Hypoalgesia in response to TENS depends on stimulation intensity. J Pain. 2011;12(8):929-35.

12. Kahn J. Principles and Practice of Electrotherapy. 3rd Edition. New York: Churchill Livingstone; 1994. Chapter 6, Transcutaneous Electrical Nerve Stimulation;123-124.

13. Polden M, Mantle J. Physiotherapy in Obstetrics and Gynaecology. New Delhi: Jaypee Brothers Medical Publishers; 1994.Chapter 7, The Postnatal Period; 223-243.

14. Vance C, Dailey D, Rakel B, Sluka K. Using TENS for pain control: the state of the evidence. Pain Management. 2014;4(3):197-209.
15. Michlovitz S, Nolan T. Modalities for therapeutic intervention. 4th Edition. New Delhi: Jaypee Brothers Medical Publishers (P), Ltd. 2008. Chapter 6, Electrotherapeutic Modalities: Electrotherapy and Iontophoresis; 109-113.

16. Knight K, Draper D. Therapeutic Modalities The Art and Science. 2nd Edition. Philadelphia: Lippincott Williams and Wilkins; 2013. Chapter 17, Application procedures: Electrotherapy; 334-338.

17. Sluka K, Walsh D. Transcutaneous Electrical Nerve Stimulation and Interferential Therapy. In: Sluka K, editor. Mechanisms and Management of Pain for the Physical Therapist. 2nd Edition. p.206-215.

18. Emmiler M, Solak O, Kocogullari C, Dundar U, Ayva E, Ela Y, et al. Control of acute postoperative pain by transcutaneous electrical nerve stimulation after open cardiac operations: a randomized placebocontrolled prospective study. Heart Surg Forum. 2008;11(5):E300-3.

19. Binder P, Gustafsson A, Uvnäs-Moberg K, Nissen E. Hi-TENS combined with PCA-morphine as post caesarean pain relief. Midwifery. 2011;27(4):547-52.

20. Chandra A, Banavaliker J, Das P, Hasti S. Use of transcutaneous electrical nerve stimulation as an adjunctive to epidural analgesia in the management of acute thoracotomy pain. Indian $\mathrm{J}$ Anesth. 2010;54(2):116-20.

21. Forster A, Palastanga N. Clayton's Electrotherapy Theory And Practice. 9th Edition. London: Bailliere Tindall, 2006. Chapter 3, Electrical Stimulation of Nerve and Muscle; p.102-106.

22. Cameron M, Shapiro S, Ocelnik M. Electrical Currents for Pain Control. In: Cameron M., editor. Physical Agents in Rehabilitation An Evidence Based Approach To Practice. 5th Edition. Missouri: Elsevier; 2018. 258-262.

Cite this article as: Mehendale PA, Revadkar MT. Effect of acupuncture TENS versus conventional TENS on post cesarean section incision pain. Int $\mathbf{J}$ Reprod Contracept Obstet Gynecol 2018;7:3738-43. 